\title{
Lekcje o wartościach
}

\author{
Classes about values
}

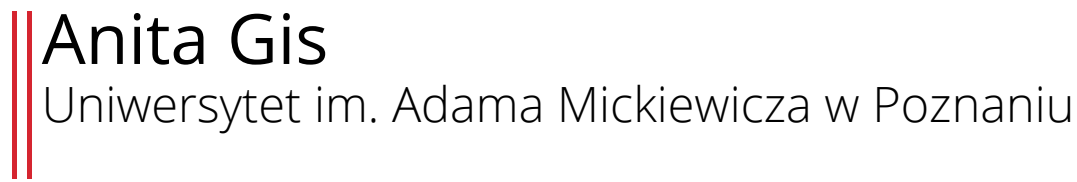

\begin{abstract}
The article deals with the subject of Polish language education as a carrier of values. Analyzes the proposals of methodological solutions that the student of a modern school meets. The article also considers which elements of the lesson relate to the learning of values and how they are modeled.

The research material is composed of materials collected by students of Polish philology at the Adam Mickiewicz University in Poznan during the course of an internship carried out in various types of schools. Organizing the collected data allows to confront theoretical assumptions with the empirical one of school life, and indicates common or overlooked features.
\end{abstract}

Key words: values, valuation, lessons of Polish language, didactic situation

Streszczenie: Artykuł porusza temat edukacji polonistycznej jako nośnika wartości. Analizuje propozycje rozwiązań metodycznych, z jakimi spotyka się uczeń współczesnej szkoły; rozważa, w jakich elementach struktury lekcji ukonkretniają się treści związane z kształceniem wartości, w jaki sposób są one modelowane.

Tworzywo badawcze stanowią materiały zebrane przez studentów filologii polskiej UAM w czasie praktyki zawodowej realizowanej w różnych typach szkół. Uporządkowanie zebranych danych pozwala na konfrontację założeń teoretycznych z empirią życia szkolnego oraz wskazuje miejsca wspólne lub pomijane.

Słowa kluczowe: wartości, wartościowanie, lekcje polskiego, sytuacja dydaktyczna

Dla współczesnego młodego człowieka ważniejsze wydaje się sportowe motto: szybciej, wyżej, dalej niż Platońska triada: dobro, piękno, prawda. Trudności „płynnego świata” - najwyżej ceniącego skuteczność, naznaczonego duchowym i etycznym niedomaganiem, brakiem jednoznacznych kryteriów moralnych - często prowadzą do zatarcia granicy między dobrem i złem, prawdą i fałszem. To właśnie dlatego uczniowie potrzebują pomocy $\mathrm{w}$ ukierunkowaniu ich ku wartościom. Jak słusznie bowiem zauważa Krzysztof Biedrzycki: „Młody człowiek, który wchodzi w świat, chce go 
zrozumieć, nawet gdy się przeciw niemu buntuje, czeka na znaki, które chaos rzeczywistości przemienią w ład. Zanim młody człowiek dostrzeże niuanse, niejednoznaczności, zanim sam wpadnie w poznawcze tarapaty, szuka punktu oparcia"1.

O wielostronnym oddziaływaniu literatury pisano od dawna ${ }^{2}$. Zdaniem Stefana Sawickiego „Dzieło literackie jest swoistym przesłaniem człowieka do człowieka. Śladem twórcy, lecz i apelem do odbiorcy"3. Definicja ta, nakreślająca aksjologiczny wymiar utworu, wpisuje się w nurt refleksji nad aktem lektury i procesu czytania ${ }^{4}$. Problematyce wartości i wartościowania na lekcjach języka polskiego poświęcone są między innymi tomy z serii „Literatura w kręgu wartości”.

Nie bez znaczenia pozostają też zachodzące od połowy XX wieku zmiany w humanistyce, ujmowane w kategoriach „zwrotów” badawczych. „Ponad wszelką wątpliwość zwrot etyczny - zdaniem Michała Januszkiewicza należy obecnie do najważniejszych zjawisk współczesnej kultury i obejmuje cały szereg obszarów: naukę o literaturze, filozofię, ale i prawo, nauki społeczne, język mediów. Swoje szczególne miejsce zajmuje zwrot etyczny w nauce o literaturze, zwłaszcza angloamerykańskiej. Ale i w Polsce coraz mocniej akcentuje się jego wagę, niezależnie od istotnych różnic w zajmowanych przez badaczy stanowiskach wobec teorii literatury" ${ }^{6}$. Tendencje właściwe dla ethical turn wskazują na problem etycznej postawy wobec tekstu - wzajemną relację między tekstem a czytelnikiem, który, poznając tekst, godzi się, by w trakcie lektury w nim samym dokonywała się zmiana.

W praktyce lekcyjnej szukałam potwierdzenia aksjologicznej lektury utworów literackich i tekstów kultury. Informacji o zaangażowaniu szkoły w realizację treści aksjologicznych dostarczyły materiały otrzymane od

\footnotetext{
${ }^{1}$ Biedrzycki K., 2008, Moja hierarchia, w: Odpowiedź na ankietę: Pisarze polscy XX wieku - przecenieni niedocenieni, w: Wartościowanie a edukacja polonistyczna, A. Janus-Sitarz (red.), Kraków, s. 81.

2 Zob. m.in. Literatura dla dzieci i młodzieży w procesie wychowania, 1978, Przecławska A. (red.), Warszawa; Nowe opisanie świata. Literatura i sztuka dla dzieci i młodzieży w kręgach oddziaływań, 2013, Niesporek-Szamburska B. i Wójcik-Dudek M. (red.), Katowice; Starzec H., 1980, Wychowanie literackie, Warszawa; Świętosławska T., 2005, Sensy i wartości. W kręgu literatury i dydaktyki, Łódź; Wartości w literaturze dla dzieci i młodzieży. Wybrane problemy, 1985, Papuzińska J., Żurakowski B. (red.), Warszawa; Żurakowski B., 1998, Literatura dla młodego odbiorcy jako przekaz świata wartości wychowawczych, w: Pedagogika społeczna jako dyscyplina akademicka. Stan i perspektywy, Hetka E., Piekarski J., Cyrańska E. (red.), Łódź.

${ }^{3}$ Sawicki S., 1992, Problematyka aksjologiczna $w$ badaniach literackich, w: Problematyka aksjologiczna w nauce o literaturze, Sawicki S., Tyszczyk A. (red.), Lublin, s. 103; Wiśniewska G., 1999, Uczyć polskiego, bawiąc i wychowując, Kielce.

${ }^{4}$ Chrząstowska B., 2009, Autor - dzieło - poetyka. Problemy interpretacji w szkole, w: Przedmiot, podmiot, proces. Szkice z metodyki kształcenia polonistycznego, Kwiatkowska-Ratajczak M., Wantuch W. (red.), Poznań; Czerkies T., 2014, Strategie uwodzenia tekstem. O odpowiedzialnej lekturze podczas zajęć na przykładzie języka polskiego jako rodzimego oraz jako języka polskiego, „Postscriptum Polonistyczne”, nr 1(13), s. 27-46; Janus-Sitarz A., 2009, Przyjemność i odpowiedzialność w lekturze. O praktykach czytania literatury w szkole, Kraków; Koziołek K., (2006), Czytanie z Innym. Etyka. Lektura. Dydaktyka, Katowice.

${ }^{5}$ Efektem prowadzonych badań pod kierunkiem S. Sawickiego są między innymi opracowania: O wartościowaniu $w$ badaniach literackich, 1992, Sawicki S., Panas W. (red.), Lublin; Problematyka aksjologiczna w nauce o literaturze, 1992, Sawicki S., Tyszczyk A. (red.), Lublin; Interpretacje aksjologiczne, 1997, Panas W., Tyszczyk A. (red.), Lublin; Wartość i sens. Aksjologiczne aspekty teorii interpretacji, 2003, Fiała E., Tyszczyk A., Zajączkowski R. (red.), Lublin.

${ }^{6}$ Januszkiewicz M., 2012, Kimjestemja , kimjesteśty. Etyka, tożsamość, rozumienie, Poznań, s. 205.
} 
studentów realizujących specjalność nauczycielską filologii polskiej UAM w Poznaniu, przekazane po zakończeniu przez nich praktyk zawodowych, przeprowadzanych we wrześniu i październiku 2017 roku w różnych typach szkół na terenie ośmiu województw.

Analiza 89 teczek praktyk, a przede wszystkim zawartych w nich dzienniczków, konspektów i sprawozdań studenckich obrazuje sposoby uczenia o wartościach w dzisiejszej szkole. Dla uczestników badania najważniejsze okazały się kwestie wychowawcze, którym poświęcili najwięcej uwagi w swoich komentarzach ${ }^{7}$. Spostrzeżenia przyszłych nauczycieli przekonują, że wartości i wartościowanie to tematy pojawiające się w statutach szkół, regulaminach, programach wychowawczo-profilaktycznych, a także w tematach lekcji wychowawczych. Potwierdzeniem są między innymi zapisy w dzienniczkach praktyk: „Wartości moimi drogowskazami”; „Do czego potrzebne są wartości?”; „Porozmawiamy o wartościach”; „Twój, mój, nasz świat wartości". Ponadto studenci odnotowują, że zagadnienia aksjologiczne bywają tematem pedagogicznych rad szkoleniowych, np.: „Rozwijanie poczucia własnej wartości”; „Czym są wartości moralne i dlaczego są potrzebne?”; „Dlaczego trzeba uczyć dzieci wartości?”; „Wychowanie do wartości”.

Najczęściej wprowadzanie uczniów w świat wartości wiąże się z włączaniem ich w obrzędowość szkolną, realizującą zadania szkolnego programu wychowawczego. Apele i uroczystości nawiązują do wydarzeń ważnych dla historii naszego kraju, np. upamiętniających rocznicę wybuchu II wojny światowej czy sowieckiej napaści na Polskę: „Po to zginęli tamci, abyśmy mogli żyć”, „Był taki wrzesien”, „Rozszumiały się wierzby płaczące...”; przywołują też wydarzenia bieżące, np.: „To, co w życiu najważniejsze”, „Pomóż i Ty...”, „Kup Pan szczotkę”. Zaskakujące jest, że w badanym materiale nie odnotowano ani jednego nawiązania do nich w czasie lekcji. Zagubiono więc ideę scalania, integrowania treści, które zachęciłyby uczniów do ujęć interdyscyplinarnych, a jednocześnie pozwoliłoby ukazać wspólny front działań dydaktycznych grona pedagogicznego. Rezygnacja z przemyślanych odniesień, myślenie życzeniowe i tworzenie pozorów edukacji aksjologicznej wskazują, że działalność szkoły w tym obszarze staje się tylko znakiem celebry szkolnej.

Przyjmując, że wartością jest wszystko to, co stanowi przedmiot potrzeb, postaw, dążeń i aspiracji człowieka ${ }^{8}$, opracowano zbiór wartości, które

\footnotetext{
${ }^{7}$ Dotyczyły one problemów wynikających z zachowania uczniów (konfliktów, nieposłuszeństwa, znerwicowania, lękliwości, nieśmiałości) i reakcji nauczyciela na takie zachowania.

8 Zob. np. Chrząstowska B., 2005, Wartości odkrywane, narzucane i postulowane w szkolnej edukacji polonistycznej, w: Polonistyka w przebudowie. Literaturoznawstwo - wiedza o języku - wiedza o kulturze - edukacja. Zjazd Polonistów, Czermińska M. (red.), Kraków, s. 307-321; Karwatowska M., 2010, Uczeń w świecie wartości, Lublin; Kłakówna Z.A., 2003, Przymus i wolność. Projektowanie procesu kształcenia kulturowej kompetencji, Kraków; Kwiatkowska-Ratajczak M., 1994, Z perspektywy wartości o prozie dla dzieci i młodzieży, Poznań; Ostrowska K., 1994, W poszukiwaniu wartości, Gdańsk; Edukacja aksjologiczna, 1994, t. 1. Wymiary - Kierunki - Uwarunkowania, Olbrycht K. (red.), Katowice; Pedagogika ogólna. Problemy aksjologiczne, 1997, Kukołowicz T., Nowak M. (red.), Lublin; Poza kryzysem tożsamości. W kierunku pedagogiki personalistycznej, 1993, Adamski F. (red.), Kraków; Wartościowanie a edukacja polonistyczna, 2008, Janus-Sitarz A. (red.), Kraków.
} 
wybrzmiewają w zebranym materiale. Wypisano 204 określenia $^{9}$, z których 47 powtarzało się na różnych etapach kształcenia.

W szkole podstawowej propagowane są tradycyjne, uniwersalne wartości, te same, które wpaja się uczniom od wielu pokoleń. Wprowadzają one dzieci w świat dobra, miłości, szacunku. Młodsi uczniowie uczą się, że najważniejszymi wartościami są uczciwość, rodzina, przyjaźń i dobro. Bezwzględnie są to wartości niezwykle cenne, o których należy mówić na lekcjach. Jednostkowe przywoływanie antywartości na tym szczeblu nauczania wynika zapewne z postawy prowadzących lekcję, którzy zakładają, że edukacja ma prowadzić ucznia do spotkania z tym, co dobre. Brakuje przykładów, które pokazywałyby, że umieszczenie pojęcia w różnych kontekstach może zmieniać jego nacechowanie aksjologiczne. W przypadku lekcji języka polskiego w szkole podstawowej mamy do czynienia z kreacją świata opartego na schemacie biało-czarnym i z prostym dokonywaniem ocen: dobry - zły.

$\mathrm{W}$ materiale związanym $\mathrm{z}$ gimnazjum nie widać już manifestacji ugruntowania wartości pozytywnych. W tym typie szkoły nie pomija się rozmów na temat antywartości, co w dzisiejszych czasach, pełnych napięcia, agresji, przemocy, dewaluacji wartości, nie pozostaje bez znaczenia. W przeciwieństwie do poprzedniego etapu kształcenia pojawia się więcej ćwiczeń dotyczących języka (np. wykorzystanie słownictwa emotywno-oceniającego, ćwiczenia wartościowania wyrażonego wprost, jak i wartościowania pośredniego).

Natomiast analizowana dokumentacja z liceum ogólnokształcącego wskazuje naprzemienność wartości i antywartości, co można uznać za wyraz troski o ucznia uwikłanego w liczne procesy społeczno-kulturowe, wymagające od niego czujności myślenia, umiejętności interpretacji i przyjmowania rozważnej i odpowiedzialnej, wolnej od nacisku postawy, dokonywania świadomego wyboru w zakresie stylu własnego życia i wyznaczanych w jego przebiegu priorytetów.

Przywołanie wartości najczęściej uwidacznia się w konspektach lekcji dla uczniów szkół podstawowych, nierzadko gości na lekcjach gimnazjalistów, licealiści natomiast omawiają je nieregularnie - za to dogłębniej. $\mathrm{Na}$ realizację treści wskazują tematy, np.:

Czy warto być uczciwym? (J. Ch. Andersen Nowe szaty cesarza).

Rozmawiamy o przyjaźni (J. CH. Andersen Królowa Śniegu).

Jakie prawdy o nas samych ukazuje Tadeusz Różewicz w Liście do ludożerców?

Pamiętajcie o ogrodach Jonasza Kofty apelem o ochronę świata.

Czy Wokulski może być autorytetem dla współczesnej młodzieży?

W poszukiwaniu wartości życia codziennego.

Wartości uwidocznione są także w celach lekcji, np.:

\footnotetext{
${ }^{9}$ Uwzględniono zapisy pojawiające się częściej niż pięciokrotnie. W szkole podstawowej odnotowano 31 określeń, w gimnazjum - 70, w liceum -103. Warto zwrócić uwagę na wyraźną tendencję - w szkole podstawowej i gimnazjum najistotniejsze są wartości dotyczące życia indywidualnego - prywatnego, znacznie mniej czasu poświęca się sprawom społeczno-politycznym. Znacznie poważniejsza i głębsza refleksja nad światem wartości pojawia się w czasie lekcji z licealistami.
} 
określa wartości ważne dla bohatera; redaguje kodeks naprawy świata; definiuje pojęcie odpowiedzialności; rozwija postawę tolerancji wobec odmienności drugiego człowieka i poszanowania ludzkiej godności; pogłębia wrażliwość na przejawy zła/ prezentuje refleksyjną postawę wobec zachowań człowieka; potrafi sformułować własną ocenę moralną; wyjaśnia pojęcie relatywizmu; rozumie, że każdy człowiek powinien odpowiadać za swoje czyny/ współpracuje w grupie.

Do zagadnienia wartości nawiązuje się w różnych fazach lekcji: wstępnej (np.: motywując uczniów pytaniem: „po co nam zwroty grzecznościowe?”); zasadniczej (np.: budując z nimi definicję szacunku, szukając argumentów „za” i „przeciw” obyczajom i zwyczajom; rozmawiając o sytuacjach, w której wychowankowie nauczyli się czegoś wartościowego, ważnego w swoim życiu); końcowej (sprowadzanej najczęściej do uzupełnienia przez ucznia zdań: „Dzisiaj dowiedziałem się, że...”, „Na dzisiejszej lekcji nauczyłem się...”, „Po dzisiejszej lekcji wiem, że wartości....”).

Treści dotyczące aksjologii są także ujęte w tematach prac domowych, np.:

Postać literacka, którą chciałbym/chciałabym naśladować.

Co, twoim zdaniem, jest ważniejsze: szczęście osobiste czy dobro ogółu?

Czy Prometeusz mógł zostawić ludzi bez opieki? Uzasadnij swoje zdanie.

Rozważ, czy sytuacje zagrożenia są sprawdzianem człowieczeństwa. Na poparcie tez przywołaj przykłady z życia, literatury i filmu.

Czy warto „zdobywać góry” i ambitnie dążyć do celu? Przedstaw i uzasadnij swoje zdanie.

O ile zapisy w pierwszych częściach konspektów (zarówno twórczych, jak i odtwórczych) dotyczące zamierzeń aksjologicznych wydają się spójne, o tyle odniesienia do wartości w toku lekcji wskazują na pewną niekonsekwencję. Zdecydowanie słabiej wypada planowanie przebiegu lekcji, widoczne są problemy w tworzeniu i budowaniu dobrych, inspirujących sytuacji dydaktycznych. To, co zaskakuje - rzadko w toku lekcji utwór literacki czy inny tekst kultury jest traktowany jako pewne i ważne narzędzie do realizacji i budowania systemu wartości, zdecydowanie częściej pojawiają się propozycje ćwiczeń kierujących się w stronę teorii literatury. Zapisy na poziomie dość ogólnym nie ujawniają sytuacji, w których dochodzi do rzeczywistej wymiany aktywności. Aktywność nauczyciela czy występującego w tej roli studenta i aktywność ucznia często się mijają. Przedstawione propozycje przypominają dość skostniały proces. Myślę, że przyczyna leży w silnym eksponowaniu własnej roli - nauczyciel, a także prowadzący lekcję student, dominuje w czasie lekcji - o czym świadczą zapisy: „nauczyciel pisze, mówi, pyta, zapisuje, prezentuje, przedstawia, wyjaśnia, wnioskuje...”. Jeśli spojrzeć jeszcze na inny aspekt komunikacji z uczniem - dominację pytań zamkniętych, łatwo o wniosek, że w szkole podstawowej wyraźniejsze jest nauczanie niż uczenie się.

Proste i nieskomplikowane ćwiczenia, np.: „wymień cechy bohatera”, „podaj cechy dobrego kolegi”, „jakich znasz bohaterów innych książek, którzy też byli odważni?” dowodzą uleganiu pokusie łatwości. Prowadzących 
lekcje zadowala to, że uczeń „wie”, w projektowanych lekcjach brakuje dążenia, by ten wiedział - „dlaczego”. Brak wnikania w motywacje postępowania bohatera prowadzi do działań powierzchownych, sprowadzających się do uproszczonego odwzorowywania, bezrefleksyjnego nazywania postaw i zachowań. Nauczyciel przekazuje to, co jemu wydaje się istotne i słuszne, bez odwołań do zdania swoich uczniów. Realizując lekcje w ten sposób, zwalnia wychowanków z odpowiedzialności za to, co się na niej dzieje. Natomiast w przypadku praktykantów dowodzi to trudności z umiejętnością przekładania poznawanych w toku kształcenia uniwersyteckiego teorii na praktykę.

Znacznie lepiej rysują się sytuacje dydaktyczne dotyczące realizacji zadań i treści aksjologicznych, przygotowane dla uczniów gimnazjum i liceum. Uwzględniają bowiem ćwiczenia pozwalające uczniom szukać, pytać, wnioskować i zadania pobudzające do refleksji. Przykładem takiej drogi dydaktycznej są ćwiczenia z lekcji dotyczących mitologii i mitów, np.:

Zinterpretuj historię Pandory. Wyjaśnij, dlaczego nadzieja pozostawała w naczyniu, które bogowie podarowali Pandorze?

Co musiałoby się wydarzyć, aby Latona i Niobe wybaczyły sobie nawzajem? Wymyśl dalszą część lub inną wersję zakończenia mitu.

Nauczanie o wartościach nie tylko wymaga od nauczyciela wiedzy aksjologicznej, ale i pomysłowości widocznej w doborze tekstów, także tych, których problematyka jest bliska uczniom, oraz umiejętności formułowania interesujących zadań i poleceń. Przemyślany przebieg lekcji ani nie zniekształca, ani nie banalizuje zagadnień. W zebranym materiale badawczym odnajdujemy takie propozycje. To zajęcia lekcyjne odwołujące się do doświadczeń i zainteresowań uczniów, przywołujące formy publicystyczne i gatunki należące do kultury popularnej, a także właściwe dla mediów elektronicznych: blog, czaty, portale społecznościowe itd, właściwie zaplanowane i prowadzone skłaniają uczniów do refleksji, do działań, porównań i wnioskowania. Przykładem jest cykl lekcji zaprojektowany dla uczniów klasy I liceum ogólnokształcącego, wykorzystujący materiał zróżnicowany, ale i atrakcyjny dla młodego człowieka, składający się z tekstów o różnej poetyce i stylu, reprezentujący rozmaite gatunki i realizujący różne funkcje, prowokujący do działania i refleksji.

Lekcja 1. „O czym mówią memy i demotywatory?”. Wydrukowane demotywatory zostały przyklejone $\mathrm{w}$ różnych miejscach $\mathrm{w}$ sali lekcyjnej. Uczniowie oglądając zdjęcia, rozmawiają o nich między sobą, nazywają swoje emocji, wrażenia; wskazują środki wyrazu, które decydują o ich odbiorze. Celem zajęć było zainteresowanie uczniów tematem wartości, wywołanie emocji, prowokowanie do komentowania, dyskusji o różnorodności form podawania informacji i spełnianej funkcji.

Lekcja 2. „Co wspólnego mają demotywatory z literaturą i nauką?” W czasie zajęć wykorzystano fragmenty Biblii dotyczące króla Salomona, 
Hymn o miłości św. Pawła; Treny (IX i XI) Jana Kochanowskiego; Nie bój się kochać i Samotność ks. Jana Twardowskiego; Manipulacja językowa (fragment) Jerzego Bralczyka. Uczniowie pracowali w grupach, porównując wskazane teksty z materiałem z Internetu i omawiając - temat, cele, środki wyrazu, wpływ na odbiorcę. Zajęcia kończyła dyskusja tocząca się wokół trzech zagadnień: stosunku autorów do świata, wizji i kondycji człowieka, spojrzenia na ludzkie życie.

Lekcja 3. „Bo wartość człowieka jest niezmienna” (Paulo Coelho, Być jak płynaca rzeka). Analiza tekstu prowadziła do autorefleksji nad wartościami w życiu człowieka oraz przedstawienia w dowolnej formie odpowiedzi na pytanie: „Jakie wartości w życiu są dla nas ważne?"

Kontynuację podjętej refleksji stanowiła praca domowa „Ja i moi rówieśnicy, czyli jacy jesteśmy naprawdę?” (metoda projektu edukacyjnego).

Innym przykładem jest realizacja tematu Dlaczego hierarchia wartości może ulec zmianie?, który pojawił się po zakończeniu cyklu lekcji związanych z Innym światem Herlinga-Grudzińskiego. Teksty, z którymi pracowali uczniowie, to: obraz Bogusława Linkego, Autobus (1956 rok), fragmenty artykułu Marka Hendrykowskiego: „Autobus” Linkego jako parodia PRL. Studium intertekstualne i utwór Jacka Kaczmarskiego Czerwony autobus. Zaplanowane cele lekcji dotyczyły kształtowania refleksyjnej postawy wobec człowieka, jego postaw moralnych i wyborów, dokonywania hierarchizacji wartości; formułowania własnej opinii, zdania, tworzenia listu otwartego do mediów z wykorzystaniem słów: konsumpcjonizm, zniewolenie, zdemoralizowanie, system wartości i zanik wartości.

Wśród konspektów dla szkoły ponadpodstawowej znalazła się propozycja pokazująca wizję świata bez wartości. Uczniowie uczestniczyli w dyskusji na temat: „Jak wyglądałby świat pozbawiony wszelkich wartości i hamulców moralnych, świat, w którym każdy robi, co chce, nie licząc się z innymi?" Przewidywali skutki działań hakera komputerowego wprowadzającego chaos w bankach; terrorystów zatruwających wodociągi, zachowań ludzi sprawiających, że świat tonie w śmieciach. Debata prowadziła w stronę ustaleń, że skutkiem rezygnacji z praw moralnych jest chaos, zdziczenie, brak bezpieczeństwa, drastyczne obniżenie się jakości życia, świat bezprawia, oraz konkluzji, że brak wartości stanowi zagrożenie dla świata.

Najczęściej przywoływaną wartością w czasie lekcji w liceum okazał się patriotyzm. Z punktu widzenia zadań szkoły i lekcji języka polskiego jego obecność w przestrzeni edukacyjnej jest oczywista. Realizowane projekty lekcji eksponowały głównie romantyczny paradygmat kulturowy, mocno osadzony w edukacji polonistycznej. W studenckich komentarzach czytamy:

Trudne zadanie, wychowanie patriotyczne nie jest przecież czymś wyizolowanym. Przemiany polityczne, społeczne, kulturowe, jakie się dokonały i dokonują, nie pozostają bez wpływu na podejście młodych ludzi do patriotyzmu. 
Uczniowie reagują różnie, ale dla wielu z nich jest to takie puste słowo, już niewiele znaczące, dlatego może rozmowy z nimi nie są porywające. Kordian, Gustaw, Konrad to nie są ich bohaterowie.

W świetle analizowanej dokumentacji wydaje się jednak, że właśnie taki model mówienia o patriotyzmie dominuje $\mathrm{w}$ przedstawianych opracowaniach. Bezsporne jest, że patriotyzm historyczny musi pozostać w szkole, ale czas, by obok niego pojawił się patriotyzm współczesny. Tak jak w przypadku każdej kwestii, również w obszarze zagadnienia aksjologii ojczyzny i patriotyzmu, odnieść się trzeba do uwarunkowań, w których egzystuje współczesny człowiek i w jakich to zagadnienie rozważa.

Lekcje polskiego z aksjologią $\mathrm{w}$ tle cechuje niewielka naprzemienność metod. Choć większość studentów deklaruje w swoich projektach, że uczy za pomocą metod aktywizujących, trudno to zauważyć w proponowanym toku zajęć. Z zapisów wynika, że prowadzący lekcje nierzadko narzucają gotowe interpretacje, bez dania uczniom szansy na większą samodzielność, przez co zaniedbują naukę uzasadniania własnych sądów. Najczęściej przywołane metody to znane i wykorzystywane w polskich szkołach od lat: pogadanka, rozmowa (niejednokrotnie błędnie określana heurezą), wykład a z nowszych, inspirowanych dzisiejszą chwilą: burza mózgów (z prymatem metody słoneczka), drama, przekład intersemiotyczny i praca w grupach.

Zadania związane z pierwszą z przywołanych metod dominują w szkole podstawowej. Polegają na dopisywaniu (rzadziej grupowaniu) określeń do podanego hasła, np.: miłość - „uczucie, sympatia, uwielbienie; matczyna, braterska, ojcowska, siostrzana; miłosny, miłośnik, miłościwy, miłowanie, miłosierdzie; umierać z miłość, pierwsza miłość, wyznać komuś miłość”.

Natomiast przykładowe zadania projektowane z przywołaniem dramy wskazują na niepełne rozumienie jej istoty. Najczęściej utożsamia się ją $\mathrm{z}$ inscenizacją. Nie są to jednak metody analogiczne. Drama nie opiera się na gotowym tekście, gdzie uczniowie mają przydzielone role i najważniejsza jest komunikacja pomiędzy aktorem a publicznością. Drama jest doświadczeniem uczestniczących, dlatego wymaga komentarza, pozwalającego lepiej zrozumieć i poznać postać, którą się przedstawia; wymaga odwołań do emocji intelektualnych, psychicznych i estetycznych, tak ważnych dla rozwoju uczuć: miłości, altruizmu, radości, współczucia, zadowolenia, ale też smutku i złości. W analizowanym materiale brakuje takich ćwiczeń.

Najczęściej wykorzystywane techniki przekładu to rysowanie i inscenizacja. W analizowanych konspektach przekład intersemiotyczny rzadko pojawia się jako swobodna ilustracja plastyczna, częściej jako zilustrowanie tekstu po omówieniu utworu (komiks, plakat, rysunek). Prowadzący lekcję zapominają, że zadania przekładowe nie mogą być celem samym w sobie i że ostatni etap pracy ucznia domaga się powrotu do tekstu.

Licencjaci słabiej radzą sobie ze skutecznością przekazu, który w dużym stopniu zależy od metod i sposobów prowadzenia lekcji. Studenci studiów magisterskich z większą świadomością uaktywniają uczniów, proponując 
im możliwość podejmowania własnych wyborów i decyzji. Wykorzystują metody ekspresywno-impresywne, dyskusyjne i praktyki pisarskiej - sytuując ucznia w różnych rolach komunikacyjnych. Nie stronią od pracy z komputerem i tablicą interaktywną.

Materiał badawczy wskazuje, że na wszystkich etapach kształcenia organizuje się pracę $\mathrm{w}$ grupach, ze względu na jej walory kształtujące i wychowawcze. Większość zapisów podkreśla, że uczy ona współpracy, kreatywności i odpowiedzialności za wspólnie wykonywane zadania.

Kolejna kwestia dotyczy wartości szczególnej - języka. Szczególnej, ponieważ jako znak naszej tożsamości, język sam jest wartością, ale służy też do wyrażania innych wartości. Bez języka nie ma wartościowania, przypisywania ocen i uzasadnień. Proces introcepcji wartości w dużej mierze zachodzi na drodze werbalizacji, podczas budowania dialogu nauczyciela z uczniem. Z tych powodów język powinien stanowić centrum działań edukacyjnych. Niestety lekcji, w czasie których polonista przypomina o wielkiej wartości języka, jest niewiele. W świetle zebranego materiału badawczego można powtórzyć za Martą Wrześniewską-Pietrzak: „w edukacji szkolnej zaniedbuje się sferę kształcenia językowego”, której celem jest „wyrabianie świadomości istniejących środków aksjologicznych czy też praktyki ich wykorzystywania" 10 .

Najczęstszym błędem popełnianym przez prowadzących lekcje, szczególnie w szkole podstawowej, związanym z rolą języka w procesie kształcenia aksjologicznego, jest arbitralne przekazywanie wiedzy o wartościach jako o normach obowiązujących w społeczeństwie. Bogatsze dydaktycznie propozycje kierowane są do gimnazjalistów i licealistów. Postawy takie, jak szczerość, uczciwość, życzliwość, szacunek, bunt znajdują odzwierciedlenie w proponowanych lekcjach. Uwzględniają kwestie prawdy i kłamstwa. Pojawiają się także propozycje dotyczące przekazu medialnego, sposobów jego budowania i odczytywania, tworzenia przez uczniów własnych aktów komunikacyjnych, z nastawieniem na cel i odbiorcę. Wartościowanie jest odzwierciedlane $\mathrm{w}$ ćwiczeniach związanych $\mathrm{z}$ badaniem języka polityki oraz reklamy. Realizacja tego typu ćwiczeń przynosi zarówno korzyści społeczne (pogłębienie świadomości), jak językowe - znajdowanie mechanizmów perswazji i manipulacji oraz wartościowania ukrytego w leksemach, budowie składniowej komunikatu. Przykładem może być realizacja następujących zadań:

Jesteś autorem współczesnego poradnika savoir-vivre`u dla nastolatków. Napisz fragment dotyczący zasad powitania i pożegnania.

„Sorry, to nie to samo co przepraszam”. Zgadzam się z tym stwierdzeniem.

Czy poprzez język można wyrazić wartości (dyskusja).

${ }^{10}$ Wrześniewska-Pietrzak M., 2009, Wybrane leksykalne sposoby wyrażania wartości $w$ pismach uczniów szkół średnich, „Poznańskie Studia Polonistyczne. Seria Językoznawcza” , t. XV, s. 116; za: https://pressto.amu.edu.pl/index.php/pspsj/article/view/2060 [dostęp: 22.04.2018] 
Dziś w mówieniu szkolnym o wartościach nie widać podziałów terytorialnych. Materiał badawczy potwierdza realizacje podobnych treści dla wszystkich uczniów, bez względu na miejsce zamieszkania i przynależność grupową. Można uznać, że źródła szkolnej wiedzy aksjologicznej są jednakowe.

Analizowany materiał badawczy dowodzi, że zadania dotyczące kszałcenia aksjologicznego ucznia, choć w różnym stopniu, realizowane są w szkole. Edukacja ucznia w tym zakresie rozpoczyna się od omówienia zasadniczych pojęć: dobro - zło, prawda - kłamstwo, na kolejnych szczeblach poszerzana o następne kategorie, np. tolerancja - nietolerancja, patriotyzm - nacjonalizm, aby na ostatnim etapie kształcenia wprowadzać uczniów w świat dylematów egzystencjalnych, które pomogą im tworzyć własny system aksjologiczny oparty na trwałych, europejskich fundamentach.

Szkolne rozmowy o aksjologii, jak pokazuje zebrany materiał, mogą być ciekawe i inspirujące, budujące równowagę między poznaniem intelektualnym a emocjonalnym. W tej trudnej materii wszystko zależy od pasji nauczyciela, jego pomysłowości, relacji z uczniami, właściwie dobranych tekstów kultury i metod pracy. Interesująco zarysowane sytuacje dydaktyczne pozwalają uczniom poszukiwać różnych rozwiązań, podejmować indywidualne decyzje; wyrażać swoje opinie, korzystać z różnych źródeł, zadawać pytania, uczyć się od siebie nawzajem i samodoskonalić się.

Zaskoczeniem okazała się najsłabsza realizacja zagadnień aksjologicznych przez praktykantów w szkole podstawowej. Nie są oni jeszcze w pełni gotowi do niesienia pomocy uczniowi w budowaniu spójnego systemu wartości. Sądzę, że nie wynika to z niezrozumienia problemu, lecz z niepełnej, nieugruntowanej jeszcze wiedzy dydaktycznej, pedagogicznej i psychologicznej i to jest główna przyczyna ograniczenia dialogicznego i refleksyjnego charakteru prowadzonych przez nich lekcji. Słaba jeszcze świadomość taksonomiczna powoduje, że najczęściej ograniczają się do najprostszych poziomów (wiedzy i jej rozumienia). Stąd dominacja zadań rozpoczynających się od: „powiedz, wskaż, przypomnij, wymień, wyjaśnij, porównaj, opisz, uporządkuj” oraz nagminnego - „zastanów się”. Oznacza to, że potrzebują ukierunkowania kompetencji, korelacji wiedzy teoretycznej opartej na najnowszych badaniach z realiami szkoły. Celowa jest pogłębiona indywidualna rozmowa ze studentem i analiza jego pracy dydaktyczno-wychowawczej prowadzonej w czasie praktyk, która poprowadzi do ocenienia samego siebie, wyprowadzania z własnych doświadczeń wewnętrznej teorii nauczania i budowania osobistego warsztatu nauczyciela.

W świetle badań dobrze wypadają propozycje wprowadzania w świat wartości na III i IV etapie kształcenia. Wysoko należy ocenić umożliwienie uczniowi poszukiwań odpowiedzi na ważne dla niego pytania, np.: Kim jestem? Kim mogę być? Co dla mnie ważne? Co mogę wybrać? Co mogę odrzucić? Lekcje pełne zainteresowania i pasji, współdziałania i rozwiązywania problemów, pozwalające uczniowi na spotkanie z samym sobą, 
rozważania o wartości samego siebie - to są przykłady najlepszych realizacji dotyczących kształcenia aksjologicznego.

\section{O Autorce:}

Anita Gis dr, adiunkt w Pracowni Innowacji Dydaktycznych Instytutu Filologii Polskiej UAM w Poznaniu. Autorka i współautorka programów i podręczników do języka polskiego oraz artykułów metodycznych z zakresu szkolnej komunikacji językowej, miejsca podręcznika na lekcjach języka polskiego, kształcenia studentów specjalności nauczycielskiej filologii polskiej i ich zaangażowania w prowadzenie zajęć dydaktycznych. 
